\title{
Performance of Apple (Malus $\times$ domestica Borkh.) Cultivars Grown in Different Chilean Regions on a Six-year Trial, Part I: Vegetative Growth, Yield, and Phenology
}

\author{
Jose A. Yuri, Claudia Moggia ${ }^{1}$, Carolina A. Torres ${ }^{2,3}$, Alvaro Sepulveda, \\ Valeria Lepe, and Jose L. Vasquez \\ Centro de Pomaceas, Facultad de Ciencias Agrarias, Universidad de Talca, \\ P.O. Box 747, Talca, Chile
}

Additional index words. Malus $\times$ domestica Borkh., vigor, yield, apple rootstock, apple cultivar

Abstract. Performance of seven apple (Malus $\times$ domestica Borkh.) cultivars ('Brookfield ${ }^{\circledR}$ Gala', 'Galaxy', 'Super Chief', 'Granny Smith', 'Fuji Raku Raku', 'Cripp's Pink', and 'Braeburn') on M.M.106 and M.9 EMLA rootstocks during their first 6 years was evaluated on a multisite trial in Chile. Second-leaf trees were planted in experimental blocks inside commercial orchards located in five major apple-producing areas in Chile (Graneros, San Clemente, Chillan, Angol, and Temuco). Tree height and volume, trunk cross-sectional area (TCA), fruit yield and size distribution, crop load, and tree phenology were assessed annually. In general, tree growth rates by the end of the third year, when they reached the desired height, were similar in all block locations. M.9 EMLA rootstock reduced tree height by $\approx \mathbf{2 0} \%$ in 'Brookfield ${ }^{\circledR}$ Gala', 'Fuji', 'Galaxy', and 'Granny Smith'. This rootstock also had 50\% smaller TCAs than M.M.106's at Year 6 in most cultivars. The highest productions in 'Brookfield ${ }^{\circledR}$ Gala', 'Galaxy', 'Granny Smith', 'Cripp's Pink', and 'Super Chief', regardless of rootstock, were obtained in San Clemente and Chillan's blocks. Although M.M. 106 trees delivered higher yields per plant, M.9 EMLA yield efficiency (no. fruit/cm² TCA) was significantly higher. In general, the higher the latitude (toward south), the later budbreak, full bloom, and harvest occurred.

The Chilean apple industry has a production area of 37,194 ha (ODEPA, 2007), producing $\approx 1.4$ million tons of apples annually, making it one of the major apple industries in the world. Its exports were over 44 million boxes to more than 70 countries during 20092010. This accounts for $\approx 60 \%$ of total apple production in the country. The remaining $40 \%$ cannot be exported as a result of lack of quality expressed as: poor red color, sun damage, small size, and pre- and postharvest physiological disorders. This is attributed to inadequate cultivar/rootstock combinations and microclimate limitations where different apple cultivars have been traditionally grown in Chile.

The main apple cultivars belong to the Gala and Red Delicious groups, 'Granny Smith', 'Fuji', 'Cripp's Pink', and 'Braeburn'. Seventy percent of the production is concentrated

Received for publication 3 Sept. 2010. Accepted for publication 20 Dec. 2010.

This work has been supported by Project \#DOOI 1150, Fondo de Fomento al Desarrollo Científico y Tecnológico (FONDEF), Chile.

${ }^{1}$ Current address: Facultad de Ciencias Agrarias, Universidad de Talca, P.O. Box 747, Talca, Chile. ${ }^{2}$ Conicyt Program "Proyecto de Inserción 2010" participant.

${ }^{3}$ To whom reprint requests should be addressed; e-mail cartorres@utalca.cl. in the VI (Libertador Bernardo O'Higgins) and VII (Maule) regions in Chile. Nevertheless, during the last decade, new plantings have been shifting south, VIII (Bio-Bio) and IX (Araucania) regions, which are believed to be better suited for apple production as a result of their milder temperature (less environmental stress), but have also a lack of experience with newly introduced cultivars and rootstocks. M.M.106 was the main rootstock used in Chile until Year 2000, after which M.9 and its sub-clones were introduced commercially for their precocity and vegetative characteristics that facilitated cultural practices such as hand thinning and pruning. M.9. plantings have steadily increased since then adding another challenge to growers, especially to those from the south of Chile (Carrasco, 2003). With high input costs (as high as US\$ 25,000/ha in fifth-leaf trees), Chilean growers are running a risk in planting new cultivars/rootstock combinations with poor local research. In 2002, a government-industry-funded project (FONDEF) was initiated to evaluate performance of most important apple cultivars grown in Chile in a multisite experiment across different apple-growing areas. Traditional appleproducing areas (VI, VII regions) were compared with the new and expanding ones further south (VIII, IX regions). MallingMerton (M.M.) 106 and M.9 EMLA rootstocks were also compared.
Plant material. A set of seven apple (Malus $\times$ domestica Borkh.) cultivars ('Galaxy', 'Brookfield ${ }^{\circledR}$ Gala', 'Super Chief', 'Fuji Raku Raku', 'Braeburn', 'Granny Smith', and 'Cripp's Pink') grafted on two virus-free rootstocks, M.M.106 and M.9 EMLA (Table 1), were planted in a 1-ha block inside commercial orchards in five apple-productive regions in Chile (Table 2; Fig. 1). Table 3 shows climatic data for each block location compiled from 2003 to 2007. Two-year-old nursery trees (trunk diameter between 16 and $19 \mathrm{~mm}$, $20 \mathrm{~cm}$ above graft union) were planted in a complete randomized block design with three blocks and three (for M.M.106) and four (for EMLA 9) trees per block with a factorial arrangement cultivar by rootstock. Trees were produced and donated by Vivero Los Olmos (San Fernando, Chile). They were trained in "Solaxe" (Lespinasse and Lauri, 1999; Trillot et al., 2002) and received the same conventional management practices of the commercial orchards where they were inserted. Trees were planted in Sept. 2002 at $4 \times 1.5-\mathrm{m}$ spacing (1667 trees/ha) for M.9 EMLA grafted trees and $4 \times 2.25 \mathrm{~m}(1111$ trees/ha $)$ for M.M.106 based on technical recommendations for these apple rootstocks in Chile.

Traits evaluated. Tree height was measured from 2003 (Year 1) until 2005 (Year 3). At this point, trees reached their commercially desired height in Chile of $\approx 3.5 \mathrm{~m}$. Trunk cross-sectional area was measured 20 $\mathrm{cm}$ above the grafting union. Tree volume was assessed during 2005-2006 (Year 4) based on spread and height from the lowest scaffold branch. Annual yields, crop load, fruit size distribution, and average fruit weight were obtained from 2004-2005 (Year 3) to 2007-2008 (Year 6) through harvests of the whole tree. Dates for budbreak, full bloom, fruit growth, and harvest were recorded annually and shown for 2005-2006 (Year 4) and 2006-2007 (Year 5) seasons. These were determined from observational data. Full bloom was defined as the date of initiation of petal fall. Fruit harvest was based on commercial maturity parameters used for each cultivar.

Fruit size distribution was expressed as accumulative yield (kg/plant) per fruit count (number of fruit in a 18.2-kg apple box) (Yuri et al., 2010). The relationship between fruit weight and fruit count size category is shown in Table 4. These data are shown for 'Galaxy' and 'Brookfield ${ }^{\circledR}$ Gala' on both rootstocks in Year 5 .

Environmental data (air temperature, solar radiation, wind speed, rainfall, and relative humidity) were recorded using automatic weather stations in each location (GroWeather; Davis Instruments, CA). Chill (h less than $7^{\circ} \mathrm{C}$ ) and heat units [growing degree-days (GDD), $10{ }^{\circ} \mathrm{C}$ base] were calculated hourly for each location (Stanley et al., 2000).

Statistical analysis. Treatments (location $x$ rootstock) effects were analyzed with analysis of variance and Tukey (honestly significant difference test) used for multiple comparisons. The general linear model procedure and the 
univariate procedure to test normality on all data sets of the SAS statistical software package (Version 8; SAS Institute Inc., Cary, NC) were used.

\section{Results and Discussion}

The exclusion of some cultivar $\times$ rootstock combinations (Table 1) conformed with technical limitations of the cultivar in a particular geographic location or onto a specific rootstock. For example, 'Braeburn' and 'Super Chief' are not available on M.9 EMLA rootstock in Chile and 'Cripp's Pink' and 'Granny Smith' do not ripen in cold climates, which are predominant in the south of Chile.

All locations have a Mediterranean climate (Table 3 ) found predominantly in central Chile. Annual rainfall (concentrated in winter)

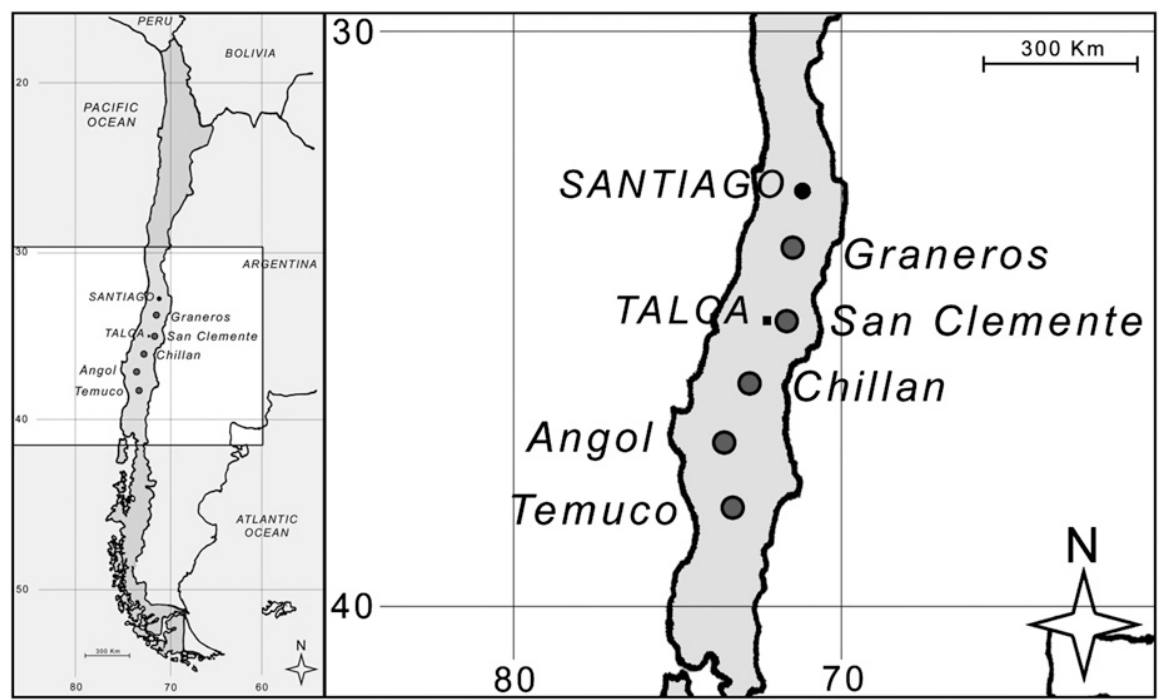

Fig. 1. Experimental block locations in Chile. increases from $390 \mathrm{~mm}$ to $1000 \mathrm{~mm}$ with latitude.

Growth rate and tree volume. Tree growth rates in 'Braeburn', 'Brookfield ${ }^{\circledR}$ Gala', 'Galaxy' and 'Super Chief' by the end of the second year after establishment were similar in all locations, except in Temuco, where they were the lowest but not always statistically different (Table 5). The opposite, in all cultivars, was observed at the end of the third year (Table 5), which allowed Temuco's block to reach similar final sizes as the other locations (data not shown). No differences in growth rates among locations were observed in either 'Fuji' or 'Cripp's Pink' by the end of the third year (Table 5).

M.9 EMLA rootstock reduced tree height by $\approx 20 \%$ in 'Brookfield ${ }^{\circledR}$ Gala', 'Fuji', 'Galaxy', and 'Granny Smith', which agrees with published literature (Ferree and Carlson, 1987; Trillot et al., 2002), but it showed a significant variation among cultivars as a result of their own genetic characteristics (Jackson, 2003; Webster and Wertheim, 2003) The average height at Year 3 for M.9 EMLA and M.M.106 was $3.3 \mathrm{~m}$ and $3.9 \mathrm{~m}$, respectively. Despite this difference, only in 'Brookfield ${ }^{\circledR}$ Gala' and 'Granny Smith', M.M.106 trees showed higher growth rates and only during the second year than the M.9 ones.

At Year 5, 'Braeburn' and 'Super Chief' on M.M.106 reached the largest tree volume $\left(6.5 \mathrm{~m}^{3}\right.$ and $2.5 \mathrm{~m}^{3}$, respectively) in the Chillan

Table 1. Cultivar and rootstock combination in each location.

\begin{tabular}{|c|c|c|c|c|c|}
\hline$\overline{\text { Cultivar/location }}$ & Graneros & San Clemente & Chillan & Angol & Temuco \\
\hline Braeburn & M.M.106 & M.M.106 & M.M.106 & M.M.106 & M.M.106 \\
\hline Fuji Raku Raku & M.9 EMLA & M.M.106, M.9 EMLA & M.9 EMLA & M.9 EMLA & M.9 EMLA \\
\hline Galaxy & M.M.106, M.9 EMLA & M.M.106, M.9 EMLA & M.M.106, M.9 EMLA & M.M.106, M.9 EMLA & M.M.106, M.9 EMLA \\
\hline Cripp's Pink & M.M.106, M.9 EMLA & M.M.106, M.9 EMLA & M.M.106, M.9 EMLA & - & - \\
\hline Super Chief & M.M.106 & M.M.106 & M.M.106 & M.M.106 & M.M.106 \\
\hline
\end{tabular}

Table 2. Sites locations in Chile.

\begin{tabular}{|c|c|c|}
\hline Productive region in Chile & Block location & Geographic coordinates \\
\hline$\overline{\mathrm{VI}}$ & Graneros & Long. $34^{\circ} 05^{\prime} \mathrm{S}$; lat. $70^{\circ} 43^{\prime} \mathrm{W} ; 483 \mathrm{masl}^{1}$ \\
\hline VIII & Chillan & Long. $36^{\circ} 32^{\prime} \mathrm{S}$; lat. $71^{\circ} 50^{\prime} \mathrm{W} ; 195 \mathrm{masl}$ \\
\hline IX & Angol & Long. $37^{\circ} 43^{\prime} \mathrm{S}$; lat. $72^{\circ} 37^{\prime} \mathrm{W}$; 195 masl \\
\hline
\end{tabular}

${ }^{\mathrm{z}}$ Meters above see level.

Table 3. Microclimate data in experimental locations. ${ }^{2}$

\begin{tabular}{|c|c|c|c|c|c|c|c|c|}
\hline $\begin{array}{l}\text { Module } \\
\text { location }\end{array}$ & $\begin{array}{l}\text { Avg temp. }\left({ }^{\circ} \mathrm{C}\right) \\
\text { (1 Oct. to } \\
30 \text { Apr.) }\end{array}$ & $\begin{array}{c}\text { Maximum } \\
\text { temp. }\left({ }^{\circ} \mathrm{C}\right) \\
(1 \mathrm{Oct} \text { to } \\
30 \mathrm{Apr} .)\end{array}$ & $\begin{array}{l}\text { Minimum } \\
\text { temp. }\left({ }^{\circ} \mathrm{C}\right) \\
\text { (1 Oct. to } \\
30 \text { Apr.) }\end{array}$ & $\begin{array}{l}\text { Chill units } \\
\left.\text { (h less than } 7^{\circ} \mathrm{C}\right) \\
\text { (1 May to } 10 \text { Aug.) }\end{array}$ & $\begin{array}{l}\text { Growth units } \\
\text { GDD } 10 \text { (1 Oct. } \\
\text { to } 30 \text { Apr.) }\end{array}$ & $\begin{array}{c}\text { Rainfall } \\
\text { (mm/year) }\end{array}$ & $\begin{array}{l}\text { Days per month } \\
\text { with winds greater } \\
\text { than } 20 \mathrm{~km} \cdot \mathrm{h}^{-1} \\
\text { (1 Oct. to } 30 \mathrm{Apr} \text {.) }\end{array}$ & $\begin{array}{c}\text { Soil } \\
\text { texture }\end{array}$ \\
\hline Graneros & 17.1 & 25.6 & 9.1 & 1035 & 1584 & 390 & 4.0 & Clay loam \\
\hline Chillan & 14.9 & 24.2 & 6.5 & 1031 & 1218 & 897 & 5.5 & Sandy loam \\
\hline Angol & 16.3 & 24.1 & 9.7 & 884 & 1403 & 911 & 21.8 & Loamy \\
\hline Temuco & 13.3 & 20.2 & 7.7 & 979 & 835 & 1002 & 16.4 & Loamy \\
\hline
\end{tabular}

${ }^{2}$ Data compiled from 2003 to 2007.

$\mathrm{GDD}=$ growing degree-days

Table 4. Fruit count size (no. of fruit in a $18.2-\mathrm{kg} \mathrm{box}^{-1}$ ) and their equivalent fruit weights.

\begin{tabular}{|c|c|c|c|c|c|c|c|c|c|c|c|}
\hline \multirow{2}{*}{$\begin{array}{l}\text { Fruit count size } \\
\text { Fruit weight (g) }\end{array}$} & & 60 & 70 & 80 & 90 & 100 & 110 & 120 & 135 & 150 & 160 \\
\hline & Upper limit & 400.0 & 269.9 & 239.9 & 217.9 & 193.9 & 171.9 & 153.9 & 137.9 & 125.9 & 117.9 \\
\hline
\end{tabular}


Table 5. Treatment effects (location $\times$ rootstock) on the difference in tree height $(\mathrm{m})$ at the end of Year 2 (Year 2-Year 1) and at the end of Year 3 (Year 3-Year 2) in 'Braeburn', 'Brookfield ${ }^{\circledast}$ Gala', 'Fuji', 'Galaxy', 'Granny Smith', 'Cripp’s Pink', and 'Super Chief'.

\begin{tabular}{|c|c|c|c|c|c|c|c|c|c|c|c|c|c|c|c|}
\hline \multirow{2}{*}{$\frac{\text { Block }}{\text { Location (A) }}$} & \multicolumn{2}{|c|}{ Braeburn } & \multicolumn{2}{|c|}{ Brookfield ${ }^{\circledR}$ Gala } & \multicolumn{2}{|c|}{ Fuji Raku Rakuz } & \multicolumn{3}{|c|}{ Galaxy } & \multicolumn{2}{|c|}{ Granny Smith } & \multicolumn{2}{|c|}{ Cripp's Pink } & \multicolumn{2}{|c|}{ Super Chief } \\
\hline & Yr 2-1 & Yr 3-2 & Yr 2-1 & Yr 3-2 & Yr 2-1 & Yr 3-2 & Yr 2-1 & \multicolumn{2}{|c|}{ Yr 3-2 } & Yr 2-1 & Yr 3-2 & Yr 2-1 & Yr 3-2 & Yr 2-1 & Yr 3-2 \\
\hline Graneros & $0.80 \mathrm{a}^{\mathrm{z}}$ & $0.54 \mathrm{~b}$ & $0.53 \mathrm{ab}$ & $0.65 \mathrm{a}$ & $\mathrm{N} / \mathrm{A}$ & $\mathrm{N} / \mathrm{A}$ & $0.51 \mathrm{ab}$ & \multicolumn{2}{|c|}{0.86} & $0.48 \mathrm{~b}$ & 0.55 & $0.56 \mathrm{~b}$ & 0.67 & $0.53 \mathrm{~b}$ & $0.33 \mathrm{~b}$ \\
\hline San Clemente & $0.97 \mathrm{a}$ & $0.78 \mathrm{~b}$ & $0.78 \mathrm{a}$ & $0.38 \mathrm{~b}$ & 0.77 & 0.59 & $0.64 \mathrm{a}$ & \multicolumn{2}{|c|}{0.44} & $0.91 \mathrm{a}$ & 0.52 & $0.82 \mathrm{a}$ & 0.64 & $0.77 \mathrm{a}$ & $0.23 \mathrm{~b}$ \\
\hline Chillan & $0.83 \mathrm{a}$ & $0.58 \mathrm{~b}$ & $0.63 \mathrm{ab}$ & $0.62 \mathrm{ab}$ & 0.82 & 0.48 & $0.53 \mathrm{ab}$ & \multicolumn{2}{|c|}{0.45} & $0.69 \mathrm{ab}$ & 0.55 & $0.79 \mathrm{ab}$ & 0.53 & $0.95 \mathrm{a}$ & $0.58 \mathrm{~b}$ \\
\hline Angol & $0.72 \mathrm{a}$ & $0.74 \mathrm{~b}$ & $0.64 \mathrm{ab}$ & $0.65 \mathrm{a}$ & 0.45 & 0.63 & $0.69 \mathrm{a}$ & \multicolumn{2}{|c|}{0.60} & $\mathrm{~N} / \mathrm{A}$ & $\mathrm{N} / \mathrm{A}$ & $\mathrm{N} / \mathrm{A}$ & $\mathrm{N} / \mathrm{A}$ & $0.76 \mathrm{a}$ & $0.59 \mathrm{ab}$ \\
\hline Temuco & $0.37 \mathrm{~b}$ & $1.3 \mathrm{a}$ & $0.35 \mathrm{~b}$ & $0.75 \mathrm{a}$ & 0.47 & 0.55 & $0.26 \mathrm{~b}$ & \multicolumn{2}{|c|}{0.76} & N/A & $\mathrm{N} / \mathrm{A}$ & $\mathrm{N} / \mathrm{A}$ & $\mathrm{N} / \mathrm{A}$ & $0.23 \mathrm{c}$ & $0.99 \mathrm{a}$ \\
\hline$P$ & 0.0003 & 0.0002 & 0.008 & 0.009 & 0.138 & 0.600 & 0.006 & \multicolumn{2}{|c|}{0.001} & 0.007 & 0.945 & 0.021 & 0.161 & $<0.0001$ & 0.001 \\
\hline \multicolumn{16}{|l|}{ Rootstock (B) } \\
\hline M.M.106 & 0.74 & 0.79 & 0.70 & 0.59 & 0.80 & 0.53 & 0.57 & \multicolumn{2}{|c|}{0.69} & 0.88 & 0.57 & 0.77 & 0.60 & 0.65 & 0.54 \\
\hline M.9 EMLA & $\mathrm{N} / \mathrm{A}^{\mathrm{y}}$ & $\mathrm{N} / \mathrm{A}$ & 0.47 & 0.63 & 0.62 & 0.57 & 0.48 & \multicolumn{2}{|c|}{0.56} & 0.51 & 0.51 & 0.68 & 0.63 & N/A & N/A \\
\hline$P$ & N/A & $\mathrm{N} / \mathrm{A}$ & 0.003 & 0.512 & 0.776 & 0.303 & 0.194 & \multicolumn{2}{|c|}{0.054} & 0.001 & 0.489 & 0.229 & 0.607 & N/A & N/A \\
\hline $\mathrm{A} \times \mathrm{B}(P)$ & N/A & $\mathrm{N} / \mathrm{A}$ & 0.071 & 0.671 & $\mathrm{~N} / \mathrm{A}$ & $\mathrm{N} / \mathrm{A}$ & 0.736 & \multicolumn{2}{|c|}{0.019} & 0.953 & 0.031 & 0.365 & 0.315 & N/A & N/A \\
\hline & & & & & & & & 106 & 9 & & & & & & \\
\hline & & & & & & \multicolumn{2}{|c|}{ Graneros } & $1.0 \mathrm{a}$ & $0.68 \mathrm{abc}$ & & & & & & \\
\hline & & & & & & \multicolumn{2}{|c|}{ San Clemente } & $0.42 \mathrm{bc}$ & $0.47 \mathrm{bc}$ & & & & & & \\
\hline & & & & & & \multicolumn{2}{|l|}{ Chillan } & $0.60 \mathrm{abc}$ & $0.30 \mathrm{c}$ & & & & & & \\
\hline & & & & & & \multicolumn{2}{|l|}{ Angol } & $0.46 \mathrm{bc}$ & $0.73 \mathrm{abc}$ & & & & & & \\
\hline & & & & & & \multicolumn{2}{|l|}{ Temuco } & $0.93 \mathrm{ab}$ & $0.59 \mathrm{abc}$ & & & & & & \\
\hline
\end{tabular}

${ }^{\mathrm{z}}$ Different letters within columns indicate statistical differences between means (Tukey, $P \leq 0.05$ ).

${ }^{\mathrm{y}} \mathrm{N} / \mathrm{A}=$ not applicable, as indicated in Table 1.

${ }^{x}$ For 'Fuji Raku Raku', only San Clemente has both rootstocks; therefore, $\mathrm{A} \times \mathrm{B}$ interaction is not applicable.

Table 6. Treatment effects (location $\times$ rootstock) on tree cross-sectional area $\left(\mathrm{cm}^{2}\right)$ at Years 1, 3, and 6 in 'Braeburn', 'Brookfield ${ }^{\circledR}$ Gala', 'Fuji', 'Galaxy', 'Granny Smith', 'Cripp's Pink', and 'Super Chief'.

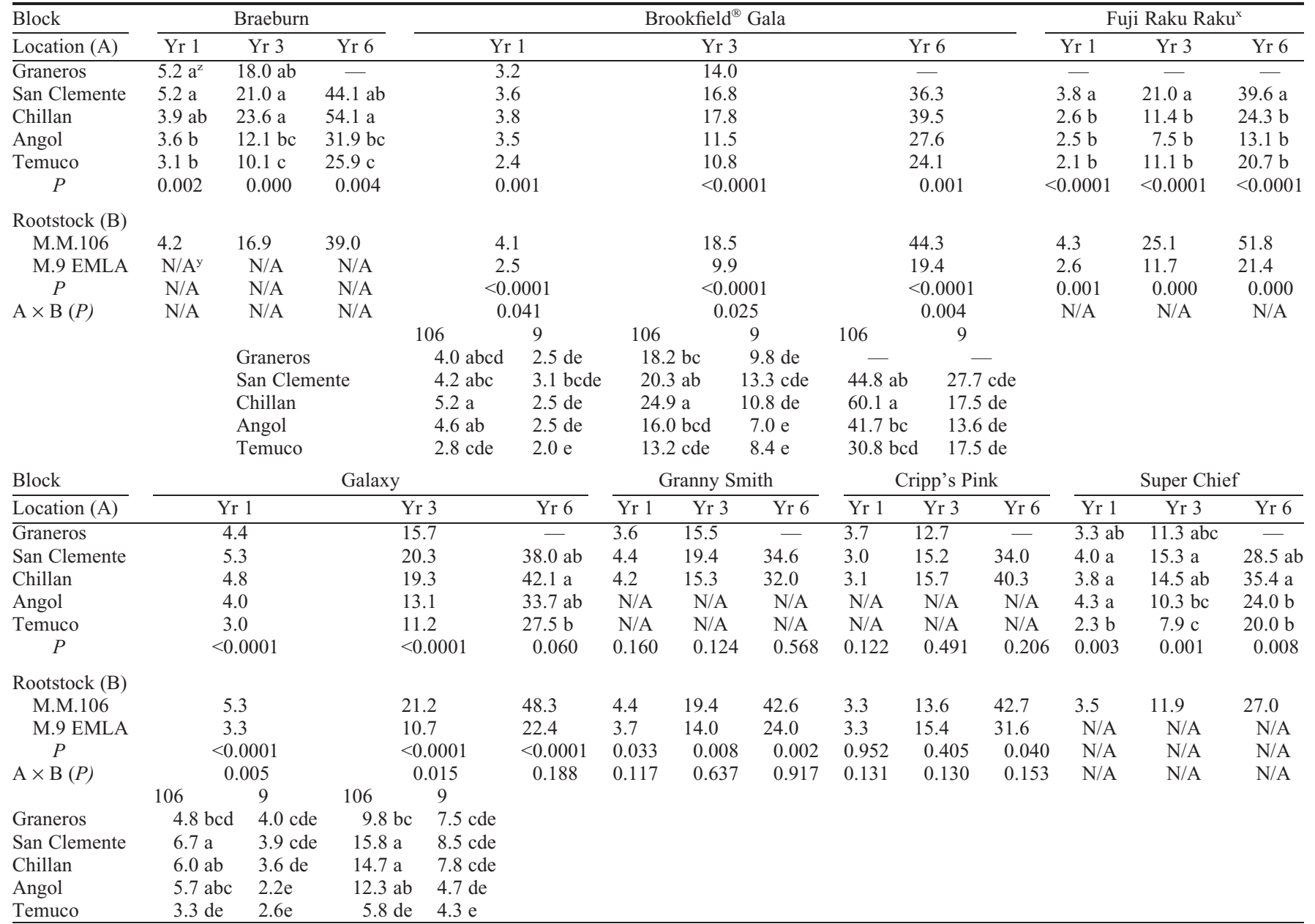

${ }^{2}$ Different letters within columns indicate statistical differences between means (Tukey, $P \leq 0.05$ ).

${ }^{y} \mathrm{~N} / \mathrm{A}=$ not applicable, as indicated in Table 1.

'For 'Fuji Raku Raku', only San Clemente has both rootstocks; therefore, A $\times$ B interaction is not applicable.

block as opposed to an average of $1.9 \mathrm{~m}^{3}$ and $1.0 \mathrm{~m}^{3}$, respectively, in the rest of the locations. In 'Galaxy' and 'Brookfield ${ }^{\circledR}$ Gala', M.9 EMLA trees showed significantly lower average volumes $\left(1.1 \mathrm{~m}^{3}, P \leq 0.05\right)$ than M.M.106s $\left(3.3 \mathrm{~m}^{3}\right)$. In 'Granny Smith' and 'Cripp's Pink', these differences were less pronounced and non-significant, except in
Chillan, where trees on M.M.106 reached larger volumes $\left(3.5 \mathrm{~m}^{3}\right.$ average in both cultivars) than on M.9 EMLA $\left(1 \mathrm{~m}^{3}\right.$ and $2 \mathrm{~m}^{3}$, respectively, $P \leq 0.05$ ). 
Table 7. Treatment effects (location $\times$ rootstock) on fruit yield $\left(\mathrm{kg} / \mathrm{plant}{ }^{1}\right)$ at Years 4, 5, and 6 in 'Braeburn', 'Brookfield ${ }^{\circledR}$ Gala', 'Fuji', 'Galaxy', 'Granny Smith', 'Cripp's Pink', and 'Super Chief'.

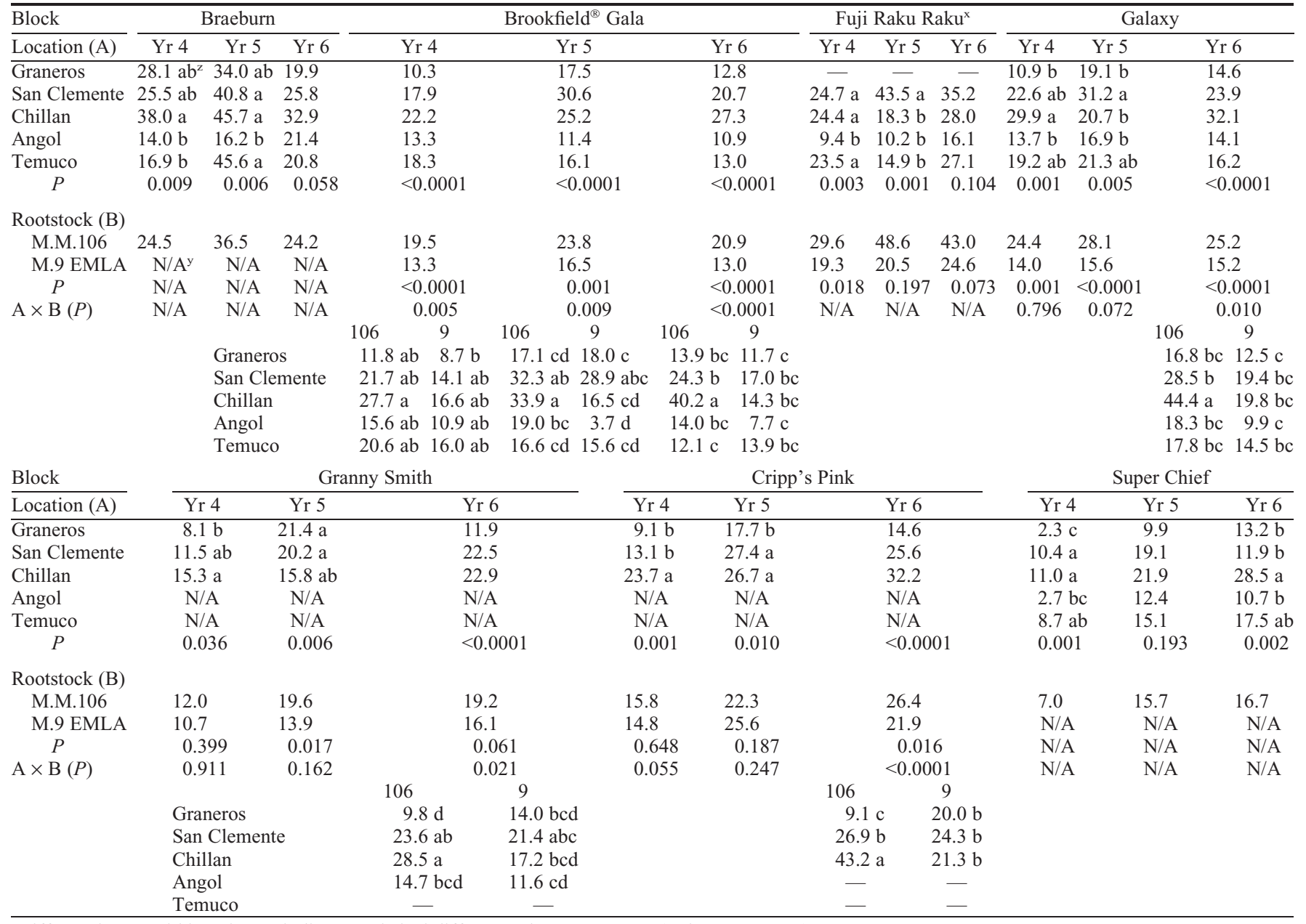

${ }^{\mathrm{z} D i f f e r e n t ~ l e t t e r s ~ w i t h i n ~ c o l u m n s ~ i n d i c a t e ~ s t a t i s t i c a l ~ d i f f e r e n c e s ~ b e t w e e n ~ m e a n s ~(T u k e y, ~} P \leq 0.05$ ).

${ }^{\mathrm{y}} \mathrm{N} / \mathrm{A}=$ not applicable, as indicated in Table 1.

${ }^{\mathrm{x}}$ For 'Fuji Raku Raku', only San Clemente has both rootstocks; therefore, $\mathrm{A} \times \mathrm{B}$ interaction is not applicable.

Trunk cross-sectional area. TCA is widely used as a measurement of tree size as a result of its linear relationship with scion weight (Barden and Marini, 2001; Westwood and Roberts, 1970). Larger TCAs at Year 1 coincided with largest TCAs at Year 6 of the experiment (Table 6). San Clemente and Chillan had the largest TCAs at Year 6, but the difference among locations was not necessarily significant (Table 6). Furthermore, trunk growth rates were also higher in larger TCAs compared with smaller ones. For example, 'Braeburn' in San Clemente, that had large TCAs, grew $7.8 \mathrm{~cm}^{2}$ per year. In contrast, the same cultivar in Temuco, with smaller TCAs at Year 1, grew $4.6 \mathrm{~cm}^{2}$ per year. Therefore, it appears that final trunk size was mainly influenced by first-year growth rather than block location. This occurred across cultivars and rootstocks except Cripp's Pink but not always statistically significant (Table 6).

In general, M.9 EMLA trees had 50\% smaller TCAs than M.M.106s at Year 6. 'Cripp's Pink' showed the least reduction of $26 \%$ average and only at the end of the trial (Table 6). This cultivar is known to be vigorous (Trillot et al., 2002); therefore, it could have outweighed the dwarfing effect of M.9
EMLA. In 'Gala' clones, the size reduction varied among locations (Table 6).

Fruit yield. 'Braeburn' and 'Fuji' showed no difference in fruit yield between blocks at Year 6. In the previous 2 years as well as accumulative, the lowest yields were observed at the Angol's block (Table 7). In all the other cultivars, the highest yields were obtained in San Clemente and Chillan blocks. In most cases, they were significantly higher than in the other three locations (further north and south) (Table 7) and in the case of 'Brookfield ${ }^{\circledR}$ Gala', 'Galaxy', and 'Granny Smith' usually associated with trees on M.M. 106 (Table 7). This result could be attributed to specific microclimate and edaphic conditions in San Clemente as well as in Chillan combined with orchard management practices in those regions. Low yields in Angol's block were likely the result of the high and frequent wind speeds during the growth season (Table 3), which if fact caused reduction of total leaf area by branch and foliage damage and also possibly high leaf transpiration rates and less insect activity, among others (Webster, 2005). Therefore, new plantings in this "new" apple-growing area in Chile must consider the use of windbreaks to obtain competitive yields.

Yield was on average $40 \%$ lower in M.9 EMLA trees compared with M.M.106s, except in 'Cripp's Pink', in which this average was only $20 \%$ in Year 6 (Table 7). Although M.9 EMLA-grafted trees yielded less fruit, the amount of fruit per TCA was higher than in M.M.106s (Table 8). In general, all cultivar/rootstock combinations, except for 'Fuji' on M.M.106, produced $\approx 20 \%$ less fruit than normally yielded in commercial operations in Chile. This was caused, partially, by a delay in plant establishment in all growing regions during the first year as a result of excessive rainfall, which reduced shoot growth, especially in M.9 EMLA trees. Another setback was second-year replanting, which was necessary in some blocks.

'Gala' clones and 'Fuji' showed no differences in accumulated yields per hectare with either of the rootstocks tested. In contrast, the highest accumulated yields per hectare in 'Granny Smith' and 'Cripp's Pink' were observed in M.9. EMLA-grafted trees (Table 7).

Crop load and fruit size distribution. There was a high variability in crop load 
Table 8. Treatment effects (location $\times$ rootstock) on crop load (fruit no. $/ \mathrm{cm}^{2}$ ) at Years 4 and 6 in 'Braeburn', 'Brookfield ${ }^{\circledR}$ Gala', 'Fuji', 'Galaxy', 'Granny Smith', 'Cripp's Pink', and 'Super Chief'.

\begin{tabular}{|c|c|c|c|c|c|c|c|c|}
\hline \multirow{2}{*}{$\frac{\text { Block }}{\text { Location (A) }}$} & \multicolumn{2}{|c|}{ Braeburn } & \multicolumn{2}{|c|}{ Brookfield $^{\circledR}$ Gala } & \multicolumn{2}{|c|}{ Fuji Raku Rakux } & \multicolumn{2}{|c|}{ Galaxy } \\
\hline & Yr 4 & Yr 6 & Yr 4 & Yr 6 & Yr 4 & Yr 6 & Yr 4 & Yr 6 \\
\hline Graneros & 6.2 & - & $4.8 \mathrm{~b}^{\mathrm{z}}$ & - & - & - & $4.1 \mathrm{~b}$ & - \\
\hline San Clemente & 4.5 & 2.8 & $5.6 \mathrm{ab}$ & $3.7 \mathrm{~b}$ & $4.7 \mathrm{~b}$ & 4.6 & $5.4 \mathrm{~b}$ & $4.0 \mathrm{at}$ \\
\hline Chillan & 6.1 & 3.4 & $8.9 \mathrm{a}$ & $5.1 \mathrm{a}$ & $8.8 \mathrm{a}$ & 6.3 & $10.3 \mathrm{a}$ & $5.4 \mathrm{a}$ \\
\hline Angol & 5.3 & 3.0 & 7.3 & $3.3 \mathrm{~b}$ & $5.3 \mathrm{ab}$ & 5.4 & $6.3 \mathrm{~b}$ & $3.3 \mathrm{~b}$ \\
\hline Temuco & 6.9 & 3.5 & $9.5 \mathrm{a}$ & $3.5 \mathrm{~b}$ & $9.0 \mathrm{a}$ & 5.8 & $9.8 \mathrm{a}$ & $3.9 \mathrm{at}$ \\
\hline$P$ & 0.476 & 0.645 & 0.008 & 0.007 & 0.007 & 0.253 & $<0.0001$ & 0.013 \\
\hline \multicolumn{9}{|l|}{ Rootstock (B) } \\
\hline M.M.106 & 5.8 & 3.2 & 6.4 & 3.5 & 2.7 & 2.3 & 6.8 & 3.7 \\
\hline M.9 EMLA & $\mathrm{N} / \mathrm{A}^{\mathrm{y}}$ & N/A & 8.1 & 4.4 & 7.5 & 6.1 & 7.6 & 4.6 \\
\hline$P$ & N/A & N/A & 0.067 & 0.012 & 0.011 & 0.001 & 0.237 & 0.021 \\
\hline $\mathrm{A} \times \mathrm{B}(P)$ & N/A & N/A & 0.595 & 0.235 & N/A & N/A & 0.227 & 0.130 \\
\hline Block & \multicolumn{3}{|c|}{ Granny Smith } & \multicolumn{3}{|c|}{ Cripp's Pink } & \multicolumn{2}{|c|}{ Super Chief } \\
\hline Location (A) & \multicolumn{2}{|c|}{ Yr 4} & Yr 6 & \multicolumn{2}{|c|}{ Yr 4} & Yr 6 & Yr 4 & Yr 6 \\
\hline Graneros & \multirow{2}{*}{\multicolumn{2}{|c|}{$\begin{array}{l}4.6 \mathrm{a} \\
1.9 \mathrm{~b}\end{array}$}} & - & \multirow{2}{*}{\multicolumn{2}{|c|}{$\begin{array}{r}10.6 \\
2.9\end{array}$}} & - & $1.1 \mathrm{~b}$ & \\
\hline San Clemente & & & $\overline{1.6}$ & & & 2.5 & $2.9 \mathrm{ab}$ & 4.7 \\
\hline Chillan & \multicolumn{2}{|c|}{$3.4 \mathrm{ab}$} & 2.0 & \multicolumn{2}{|c|}{4.3} & 4.1 & $4.0 \mathrm{ab}$ & 3.8 \\
\hline Angol & \multicolumn{2}{|c|}{ N/A } & $\mathrm{N} / \mathrm{A}$ & \multicolumn{2}{|c|}{ N/A } & N/A & $5.3 \mathrm{a}$ & 5.3 \\
\hline Temuco & \multirow{2}{*}{\multicolumn{2}{|c|}{0.034}} & \multirow[b]{2}{*}{0.125} & \multirow{2}{*}{\multicolumn{2}{|c|}{$<0.0001$}} & N/A & $1.1 \mathrm{~b}$ & 3.1 \\
\hline$P$ & & & & & & 0.017 & 0.014 & 0.308 \\
\hline \multicolumn{9}{|l|}{ Rootstock (B) } \\
\hline M.M.106 & \multicolumn{2}{|c|}{3.1} & 1.3 & \multicolumn{2}{|c|}{7.3} & 2.3 & 2.9 & 4.2 \\
\hline M.9 EMLA & \multirow{2}{*}{\multicolumn{2}{|c|}{$\begin{array}{l}3.5 \\
0.525\end{array}$}} & 2.2 & & & 4.3 & N/A & N/A \\
\hline$P$ & & & 0.003 & & & 0.005 & N/A & N/A \\
\hline $\mathrm{A} \times \mathrm{B}(P)$ & 0.9 & & 0.148 & & & 0.974 & N/A & N/A \\
\hline & & & & 106 & 9 & & & \\
\hline & $\mathrm{Gr}$ & & & $15.3 \mathrm{a}$ & $5.8 \mathrm{~b}$ & & & \\
\hline & Sar & ement & & $2.1 \mathrm{~b}$ & $3.7 \mathrm{~b}$ & & & \\
\hline & $\mathrm{Ch}$ & & & $4.4 \mathrm{~b}$ & $4.2 \mathrm{~b}$ & & & \\
\hline
\end{tabular}

${ }^{2}$ Different letters within columns indicate statistical differences between means (Tukey, $P \leq 0.05$ ).

${ }^{y} \mathrm{~N} / \mathrm{A}=$ not applicable, as indicated in Table 1.

${ }^{\mathrm{x}}$ For 'Fuji Raku Raku', only San Clemente has both rootstocks; therefore, A $\times$ B interaction is not applicable.

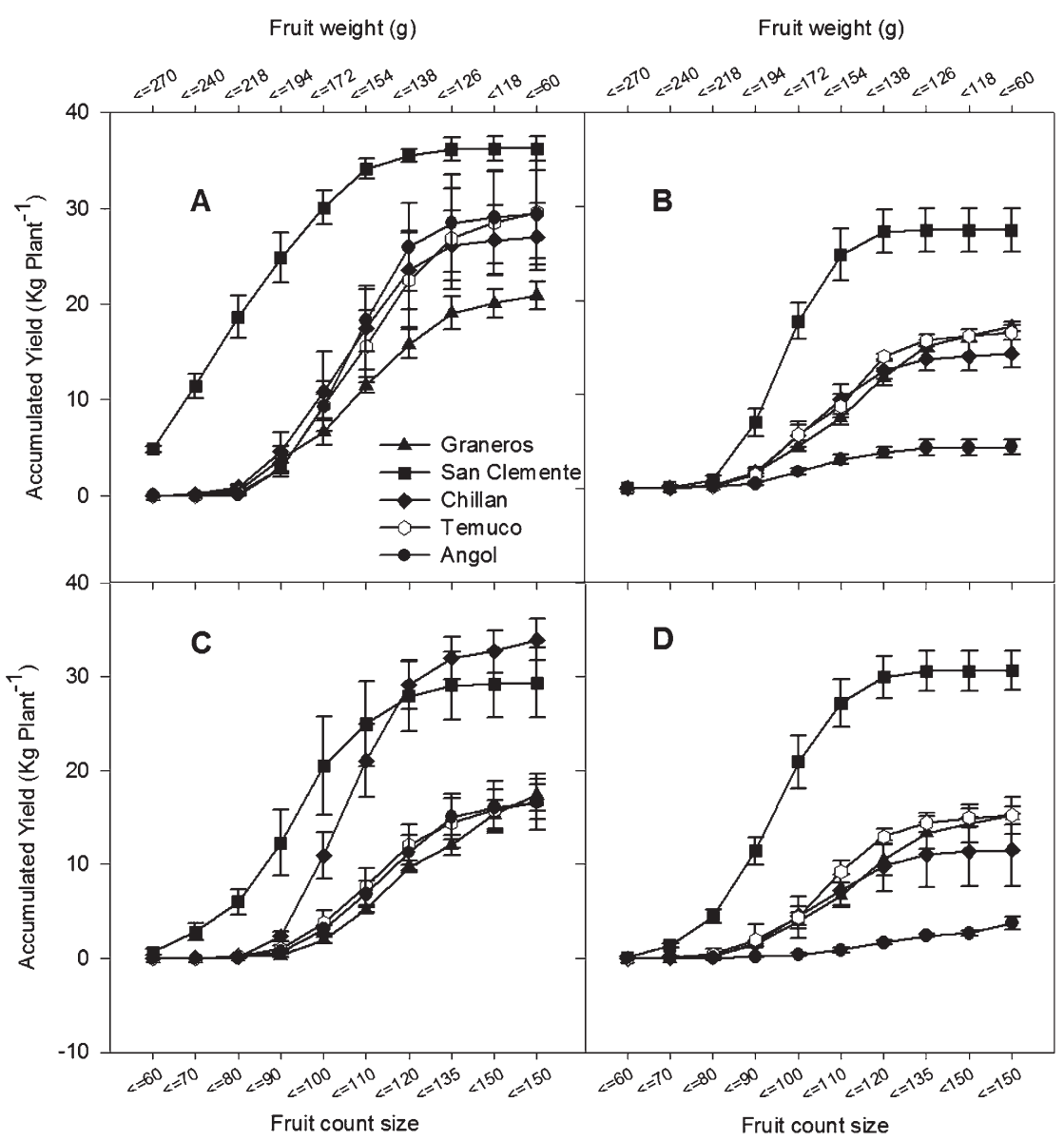

Fig. 2. Accumulated fruit count size in 'Galaxy' (A-B) on M.M.106 (A) and M.9 EMLA (B) and 'Brookfield ${ }^{\circledR}$ Gala' (C-D) on M.M.106 (C) and M.9 EMLA (D) in Year 5 for each block location. Locations arranged north to south. Means and SES $(n=3)$ are presented. among block locations with no clear pattern among cultivars (Table 8). Although M.M.106 rootstocks delivered higher yields, the yield efficiency of M.9 EMLA trees was significantly higher (with some exceptions) as a result of smaller TCAs (Tables 6 and 7). When fruit size distribution was analyzed, in general, San Clemente's block productions were not only the highest for most cultivars, but also the ones with the highest proportion of larger fruit (greater than 110 fruit count; Fig. 2). 'Galaxy' and 'Brookfield ${ }^{\circledR}$ Gala' yielded less and smaller fruit on M.9 EMLA in all regions, but especially in the Angol's block (Fig. 2). The high wind speeds in this location (Table 3 ), as mentioned earlier, affected not only vegetative growth, but also bee flight during pollination, which affected fruit yield.

Cultivar phenology. There is a clear trend showing that as latitude increases toward the south, tree phenology stages such as budbreak, full bloom, and harvest are delayed (Fig. 3). This is directly related to temperature profiles in each location. The average temperature, as well as GDD 10, during the growth season decreases toward the south (Table 3). Although Angol is south of Chillan, its temperature profile is warmer than expected and similar to San Clemente's (Table 3 ), but it has higher rainfall and high wind speeds during the growing season. For this reason, tree phenology in this block does not always represent Angol's latitude.

Full bloom occurred with $2.2 \mathrm{~d}$ (in average) difference per latitude degree (delay toward south) in 'Galaxy', 'Brookfield ${ }^{\circledR}$ Gala', 'Fuji' and 'Super Chief'. This average was $1.4 \mathrm{~d}$ in 'Cripp's Pink' and 'Granny Smith'. Coincidentally, the first group of cultivars mentioned had later blooming dates than the second group (Fig. 3). Kronenberg (1988) and Wagenmakers (1994) reported an average of $2.5 \mathrm{~d}$ difference per latitude degree on apple cultivars growing in Europe from $44^{\circ}$ to $56^{\circ}$ northern latitudes.

The start of commercial harvest was delayed toward higher latitudes $\approx 7 \mathrm{~d}$ per degree for 'Gala' clones such as 'Brookfield ${ }^{\circledR}$ ' and 'Galaxy' and $3 \mathrm{~d}$ per degree for late cultivars such as 'Fuji' and 'Cripp's Pink' (Fig. 3). The rest of the cultivars fell in between these two extremes (Fig. 3). This phenomenon can be associated with decreasing heat units toward the south (Table 3).

\section{Conclusion}

Microclimates as well as management practices in different productive areas in Chile have a profound effect on vegetative and fruiting behavior of scion/rootstock combinations, which was shown in this long-term trial. San Clemente, which is one of the areas with high apple productions, also obtained the highest yields in most cultivars in this trial. This was the result of both a suitable microclimate for apple-growing and optimal management practices. Angol, south of San Clemente, has a similar temperature profile and management practices, but many days with high wind speeds during the growing 


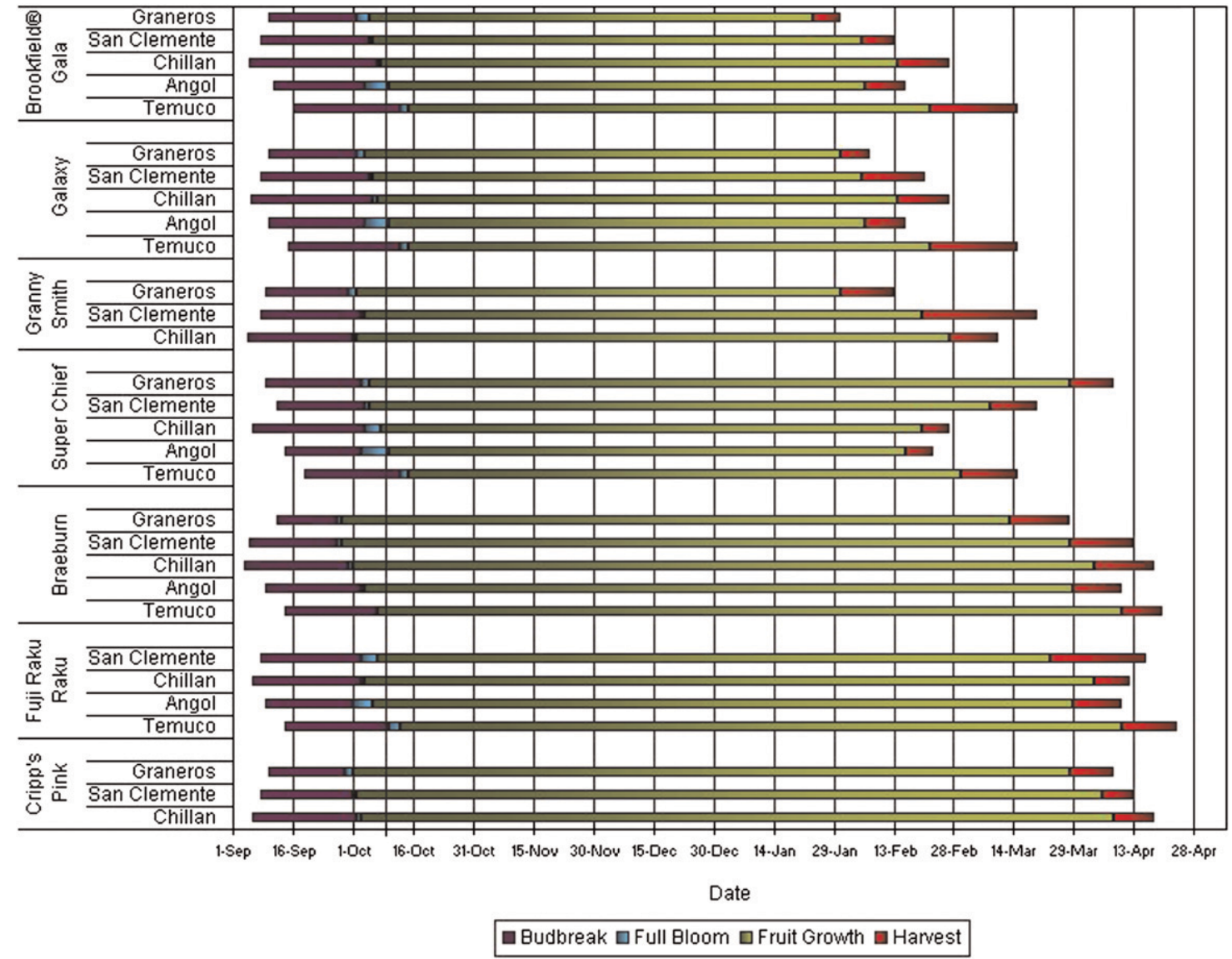

Fig. 3. Cultivar phenology on M.M.106 rootstock by block location. Seasons 2005-2006 to 2006-2007.

season lead to high detrimental microclimate conditions for fruit crops. Thus, windbreaks in this area are essential to achieve high apple productions and top-quality fruit as well as support structures, especially for M.9 clones.

Yields per year and accumulative yield during the last 3 years of the trial in some cultivars were lower than those of current commercial operations in Chile. This, as a result of some establishment problems, could have been overcome with time and not seen in the length of this trial. In future comparative trials of genotypes in use by the industry, long-term evaluations in already established orchards in different areas would be a better option if the objectives are to find the best area or microclimate to grow a certain apple cultivar.

\section{Literature Cited}

Barden, J.A. and R.P. Marini. 2001. Comparison of methods to express growth, size, and productivity of apple trees. J. Amer. Pom. Soc. 55:251-256.
Carrasco, O. 2003. El portainjerto M.9 y sub-clones de mayor relevancia. Revista Fruticola 24:41-50.

Ferree, D.C. and R.F. Carlson. 1987. Apple rootstocks, p. 107-143. In: Rom, R.C. and R.F. Carlson (eds.). Rootstocks for fruit crops. Wiley, New York, NY.

Jackson, J.E. 2003. Biology of apples and pears. Cambridge University Press, Cambridge, UK.

Kronenberg, H.S. 1988. Temperature requirements for growth and ripening of apples. Neth. J. Agr. Sci. 36:23-33.

Lespinasse, J.M. and P.E. Lauri. 1999. Integration des nouveaux concepts de conduite dans le systeme Solaxe. Revue Suisse Vitic. Arboric. Hort. 31:167-171.

ODEPA. 2007. VII Censo Agropecuario, 2007. Ministerio de Agricultura, Gobierno de Chile, Santiago de Chile, 25 Sept. 2010. $<$ http//www. odepa.gob.cl>.

Stanley, C.J., D.S. Tustin, G.B. Lupton, S. McArtney, W.M. Cashmore, and H.N. de Silva. 2000. Towards understanding the role of temperature in apple fruit growth responses in three geographic regions within New Zealand. J. Hort. Sci. Biotechnol. 75:413-422.

Trillot, M., A. Masseron, V. Mathieu, C. Hutin, and Y. Lespinasse. 2002. Le pommier. Editions
Centre technique interprofessionnel des fruits et legumes, Paris, France.

Wagenmakers, P.S. 1994. Light relations in orchard systems. Thesis, Wageningen.

Webster, A.D. 1995. Rootstock and interstock effects on deciduous fruit tree vigour, precocity, and yield productivity. N. Z. J. Crop Hort. Sci. 23:373-382.

Webster, A.D. 2005. Sites and soil for temperate tree-fruit production: Their selection and amelioration, p. 12-25. In: Tromp, J., A.D. Webster, and S.J. Wertheim (eds.). Fundamentals of temperate zone tree fruit production. Blackhuys Publishers, Leiden, The Netherlands.

Webster, A.D. and S.J. Wertheim. 2003. Apple rootstocks, p. 91-124. In: Ferree, D.C. and I.J. Warrington (eds.). Apples: Botany, production and uses. CABI Publishing, Wallingford, UK.

Westwood, M.N. and A.N. Roberts. 1970. The relationship between trunk cross-sectional area and weight of apple trees. J. Amer. Soc. Hort. Sci. 95:28-30.

Yuri, J.A., J. González-Talice, J. Verdugo, and A. del Pozo. 2010. Responses of fruit growth, quality, and productivity to crop load in apple cv. Ultra Red Gala/MM111. Sci. Hort. 127:305-312. 